\title{
Decentralized Wastewater Treatment System Impact Assessment on Groundwater Resources: Case Study Dana Biosphere Reserve/Jordan
}

\author{
Ramia Al-Ajarmeh ${ }^{1} \&$ Mahmoud Al-Alawneh ${ }^{2}$ \\ ${ }^{1}$ Department of Civil Engineering, The University of Jordan, Amman, Jordan \\ ${ }^{2}$ Ministry of Water and Irrigation/ Water Authority of Jordan, Amman, Jordan \\ Correspondence: Ramia Al-Ajarmeh, Department of Civil Engineering, University of Jordan, Queen Rania St., \\ Amman 11942, Jordan. Tel: 962-776-503120. E-mail: r.ajarmeh@ju.edu.jo
}

Received: January 1, 2019

Accepted: January 26, 2019

Online Published: February 26, 2019

doi:10.5539/mas.v13n3p58

URL: https://doi.org/10.5539/mas.v13n3p58

\begin{abstract}
Jordan is one of the world's most water-scarce countries. Almost all of the water supply systems in Jordan depend on groundwater and springs which are highly depleted. While only 60 percent of households in Jordan are connected to the sewage systems. Hence, there is a significant, untapped potential for decentralized approaches for wastewater management. DWWTS are environmentally sound and sustainable technology can be used for suburban and rural communities such the ones found in the Dana Biosphere Reserve area. Groundwater contamination risk is the critical point when implementing wastewater treatment systems including DWWTS. DRASTIC Model, an inexpensive method for evaluating the vulnerability of groundwater resources to pollution based on hydrogeologic settings, was applied to assess the groundwater contamination vulnerability in the study area. The DRASTIC index value indicates that the potential for polluting groundwater is low. This study recommends implementing DWWTS to serve communities in Dana Biosphere Reserve area emphasizing the development of groundwater monitoring program during the operation of the facility.
\end{abstract}

Keywords: Dana Biosphere Reserve, Decentralized Wastewater Treatment System (DWWTS), DRASTIC model, Groundwater

\section{Introduction}

Jordan ranks amongst the world's most water-scarce countries, and the limited water resources are being heavily overexploited. About 80 percent of the Jordan is steppe and desert where water is minimally available. Almost all of the municipal water supply systems and industry in Jordan depend on groundwater and springs. Most of these sources are currently being extracted to or beyond the capacity of the reliable aquifer yields (Jordan Ministry of Water \& Irrigation, MWI 2012).

Currently, only around 60 percent of households in Jordan are connected to the sewage systems. Hence, there is a significant, untapped potential for decentralized approaches for wastewater management.

Decentralized wastewater treatment systems (DWWTS) have low energy requirements, environmentally sound, and sustainable technology as well as low operation and maintenance requirements which can be used for suburban and rural communities (i.e., for wastewater flows from $1-500 \mathrm{~m}^{3}$ per day). DWWTS is based on four treatment systems (Sasse 1998):

- Sedimentation and primary treatment in sedimentation ponds, septic tanks or Imhoff tanks

- Secondary anaerobic treatment in fixed bed filters or baffled septic tanks (baffled reactors)

- Secondary and tertiary aerobic/anaerobic treatment in constructed wetlands (subsurface flow filters)

- Secondary and tertiary aerobic/anaerobic treatment in ponds

No adequate wastewater treatment plant exists in the Dana Biosphere Reserve area. The existing septic tanks are non-regularly emptied; potential groundwater pollution due to leakages, pollution of the wadi with the effluent as the treatment process is neither complete nor efficient.

The study aims to evaluate the vulnerability of the groundwater in Dana Biosphere Reserve using the DRASTIC model if DWWTS used in the reserve area, the empirical model of the U.S. Environmental Protection Agency, which utilizes the parameters: Depth to water, net Recharge, Aquifer media, Soil media, Topography, Impact of 
vadose zone, and hydraulic Conductivity (US EPA, 1985).

\section{Material Studied}

MWI has developed a Decentralized Wastewater Management Policy in 2016 (MWI, 2016) which is an integral part of the National Water Strategy, related policies, and action plans. This policy has shaped Jordan approach to planning, implementing and operating decentralized wastewater management infrastructure over the next decade. The policy key objectives are Sustainable Development; Public Health and Environmental Protection; Coping with Water Scarcity; Improving Local Livelihoods; Water Quality; Improving Wastewater Services; Public and Private Sector Participation; and Adaptation to Climate Change. Moreover, the policy determined the requirements for the sustainability of decentralized wastewater management infrastructure.

Decentralized wastewater management contributes significantly to reduce water scarcity by an estimated amount of up to $64 \mathrm{MCM}$ per year followed by associated improvements in groundwater protection and incremental accommodation of new growth in communities. DWWTS can service locations that cannot be serviced by centralized systems due to technical and financial limitations.

In 2016, A Project "Decentralized Wastewater Management for Adaptation to Climate Change in Jordan" (ACCProject) used as a measure for adaptation to climate change (GIZ/ACC project, 2016). This project is carried out in cooperation with the Jordanian Ministry of Water and Irrigation (MWI) via the Water Authority of Jordan (WAJ).

As an adaptation measure the GIZ/ACC project promotes efficient use of water resources by a twofold approach: (i) groundwater resources are protected by reduced pollution with untreated wastewater; (ii) treated wastewater is reused thus substituting freshwater. In this regard the project targets to promote robust, easy-to-build, easy-tooperate, proven, flexible and sustainable decentralized wastewater treatment (DWWT) technologies in combination with the reuse of treated wastewater.

A preliminary environmental impact assessment (PEIA) study was prepared by ECO Consult and ECODIT (2015) for Dana Village Restoration Project which owned by RSCN and funded by the United States Agency for International Development (USAID). Despite the presence of community hotels at Dana village within Dana Biosphere Reserve, several occupied houses and thousands of tourists each year, there is neither functioning sewage system nor treatment facility in the village. RSCN aims to implement the restoration project to improve the wastewater infrastructure based on DWWT technology of constructed wetlands. PEIA study concluded that Environmental Mitigation and Monitoring Plan could manage the environmental impacts of the project.

Feynan Ecolodge, located on the western edge of Dana Biosphere Reserve (the study area), was designed to be a model of environmentally friendly accommodation, its success evidenced by its selection as one of the top 50 desert ecolodges in the world in 2009 by National Geographic Magazine (Jamaliah \& Powell, 2017).

Feynan Ecolodge Integrated Potential Water and Wastewater Treatment Solutions - Blind Design has been developed by IWRM Alumni Association in 2014. The study team has outlined several treatment options which consider the particular requirements of Feynan Ecolodge based on DWWT methods (i.e., constructed wetlands, anaerobic baffled reactor, and anaerobic filter).

A preliminary environmental impact assessment (PEIA) study was prepared by REEC (2018) for implementing a DWWT infrastructure at Feynan Ecolodge which managed by EcoHotels and funded by GIZ/ACC project. The PEIA study concluded that the key environmental impacts of the project could be controlled by the Environmental Management Plan including groundwater monitoring.

\section{Description of the Study Area}

Dana Biosphere Reserve is Jordan's largest biosphere reserve established in 1993 and managed by RSCN, it covers $291 \mathrm{~km}^{2}$ of some of the most diverse landscape in Jordan (Figure 1) and located within Tafila Governorate/South Jordan. Dana Biosphere Reserve is the only reserve in Jordan that encompasses the four different bio-geographical zones of the country (Mediterranean, Irano-Turanian, Saharo-Arabian, and Sudanian). There are three separate accommodations are offered to the visitors to Dana; Dana Guesthouse, Rummana Campsite and Feynan Ecolodge (RSCN, 2019) in addition to rural communities such as Dana village.

\subsection{Topography}

The general topography of the study area is rolling to hilly with some steep wadis. The range in altitude on the scarp slope varies from approximately $300 \mathrm{~m}$ above sea level at the Ghuwayr - Dana confluence on the alluvial plain to $1300 \mathrm{~m}$ above sea level on the plateau. 


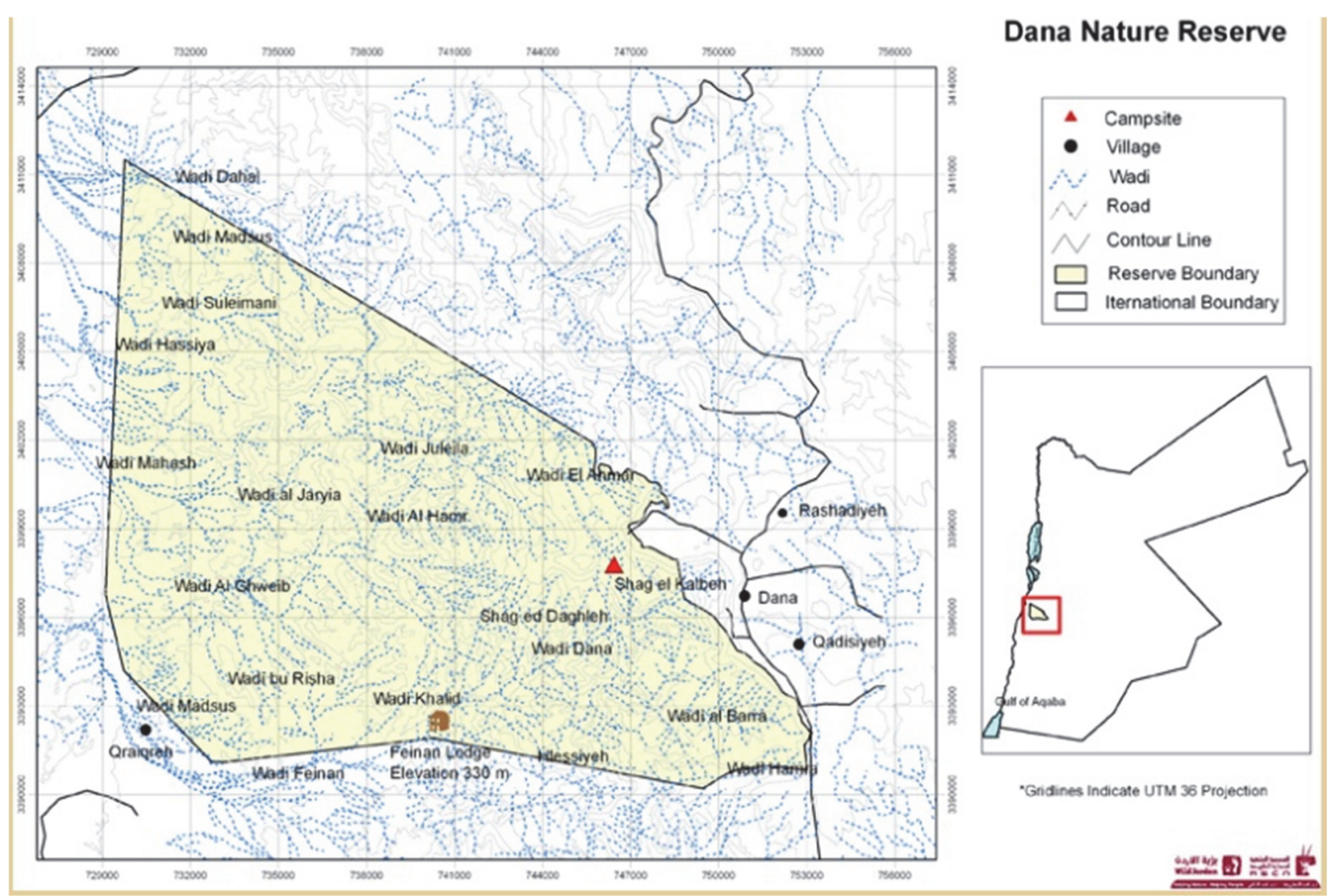

Figure 1. Dana Biosphere Reserve Location, Jordan (source: Wild Jordan/RSCN)

\subsection{Climate}

The climate of the study area is classified as semi-arid. The potential annual evaporation exceeds precipitation and is characterized by relatively cold winters, with occasional rain, and mild to hot summers. According to the long term recorded data at Dana station (main climatology station near the study area), the rate of annual rainfall in the winter is about $200 \mathrm{~mm}$ and the temperature ranges from $15-45^{\circ} \mathrm{C}$ (Jordan Meteorological Department, 2018).

\subsection{Geology}

The study area lies on the eastern side of the Wadi Araba, the southern part of the Dead Sea Transform (DST) Fault System, in an area where other major faults include the Dana and Salawan, which also cross-cut the area in an east-west direction. The most prominent features of the area are the variety of crystalline basement rocks, the main units of which are the 'Aqaba Complex' and the 'Araba Complex.' Both complexes are comprised of Late Proterozoic plutonic granitoids and extrusive (volcanic) acid and underlying rocks, and dikes of variable composition from basalt-dolerite to ryholite. These basement rocks are overlain by a long sequence of stratified rocks, which include various formations of sandstones, siltstones, shales, and limestone of Lower Paleozoic and Mesozoic age (Bender, 1974; Powell et al., 2014).

These early sedimentary strata are overlain by a further sequence varying between sandstones and limestone, the Disi and Kurnub sandstone formations and the Na'ur limestone formation.

\subsection{Water Resources}

The study area is part of Wadi Araba North basin (Figure 2). The range of depth to water in the basin is from $25 \mathrm{~m}$ to $80 \mathrm{~m}$, while the range of well depth is from $50 \mathrm{~m}$ to $300 \mathrm{~m}$ (JICA, 2001). The aquifer system in the basin consists of:

- The upper aquifer system: alluvial aquifer.

- The intermediate aquifer system: Amman-Wadi Sir (A7/B2), Nau'r Aquifer(A1/2) and Hummar Aquifer (A4).

- $\quad$ The deep aquifer system: Rum and Kurnub. 
The A7/B2 formation is considered to be the most important groundwater reservoirs in the study area. It is composed of limestone, marly limestone with chert bands, chalk, and dolomite limestone.

Springs water within Wadi Araba North basin, where the study area is located, is the primary sources for drinking water and irrigation activities. The altitudes of the springs range from 660-1540m (Al-Khashman et al., 2017). Springs are also found in the Wadi Dana and are used to irrigate gardens and to supply a hotel, but rarely any surface water flows in the wadis.

\section{Method}

To determine the impact of DWWTS implementation and if it causes any unexpected risk to groundwater contamination, DRASTIC Model was applied to assess the groundwater contamination vulnerability in the study area.

The DRASTIC model was developed by US EPA as "A Standardized System for Evaluating Groundwater Pollution Potential of Hydrogeology Settings." The model provides an inexpensive method for evaluating the vulnerability of groundwater resources to pollution based on hydrogeologic settings. It simulates the pollutant transfer time from the topsoil to the groundwater system. The numerical value for the DRASTIC index is a combination of rating and weights (US EPA, 1985).

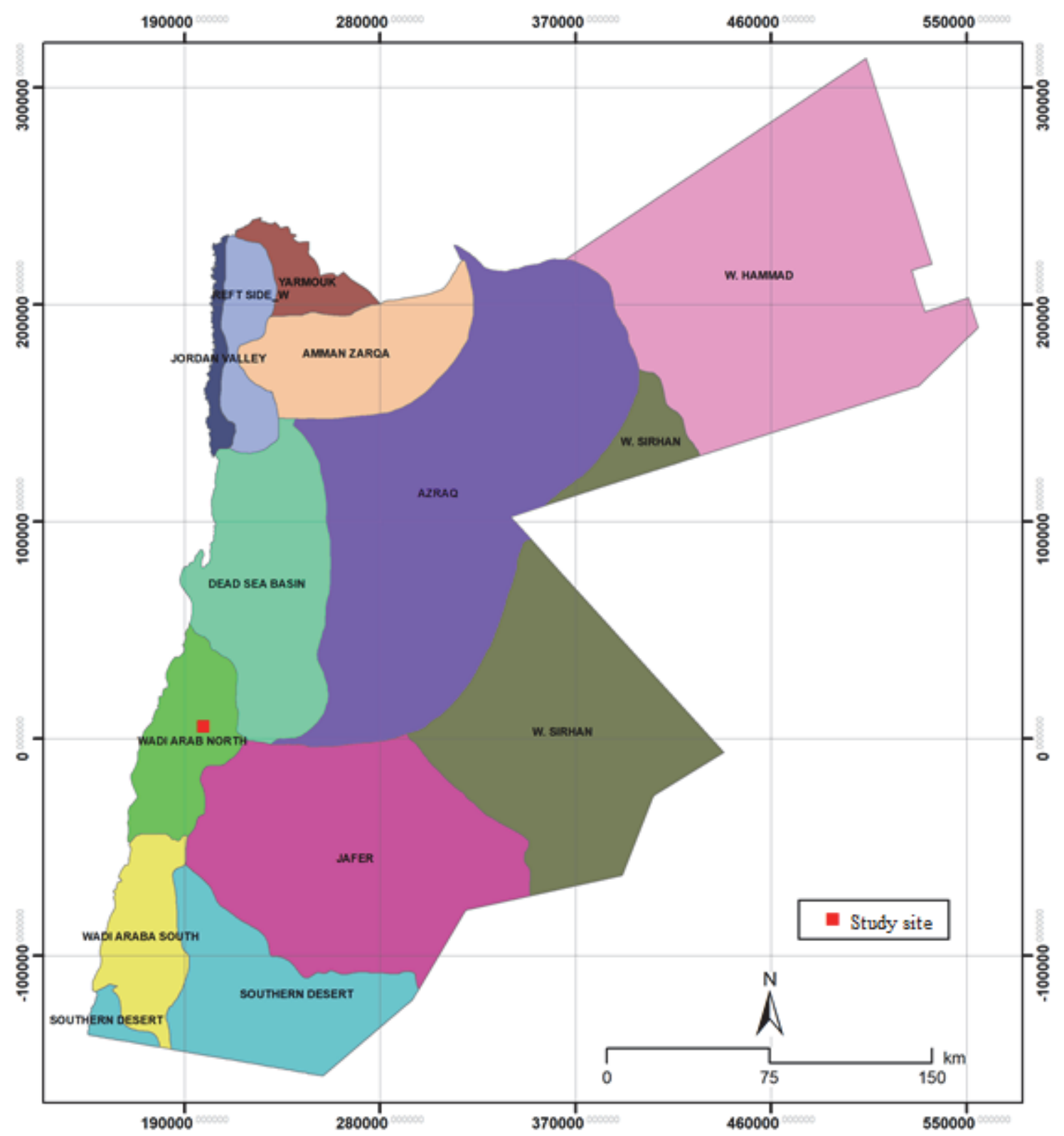

Figure 2. Study Site at Wadi Araba North Groundwater Basin 
There are many measurable factors for each hydrogeologic setting related to DRASTIC methodology. These factors include (US EPA, 1985):

- $\quad$ Depth to Water (D): There is a greater chance for the contamination to reach and pollute the groundwater at shallow aquifer more than deep aquifer.

- $\quad$ Recharge (R): More recharge to the aquifer (in or around the study site), means more possibility of the pollution to be transported to the groundwater.

- Aquifer Media (A): The material of the aquifer determines the mobility of the contamination through it. An increase in the time of travel of the pollutant through the aquifer results in more attenuation of the contamination.

- $\quad$ Soil Media (S): Soils contain clays and silt will have large water holding capacity, and thus increase the travel time of the contamination through the root zone.

- Topography /Slope (T): When the topography of the land surface is at a higher slope, the lower pollution potential due to higher runoff and erosion rate. These include the pollutants that infiltrate into the soil.

- Impact of the Vadose Zone Material (I): The unsaturated zone above the water table is referred to as a vadose zone. The texture of the vadose zone determined how long contamination will travel through it.

- Hydraulic Conductivity (C): The amount of water percolating to the groundwater is determined by hydraulic conductivity. The pollutant travel time is decreased within the aquifer if the soil has high permeability.

The DRASTIC model uses a numerical relative rating and weight system that contains:

- $\quad$ Rating: Each range for each DRASTIC factor has been evaluated concerning others to determine the relative significance of each range with respect to pollution potential. The rating of the DRASTIC factor is from 1 to 10.

- $\quad$ Range: Each DRASTIC factor has been divided into either ranges or significant media types which have an impact on pollution potential.

- Weight: The weight represents an attempt to define the relative importance of each factor in its ability to affect pollution transport to and within the aquifer. Its range from 1 to 5 .

\section{Results and Discussion}

Table 1 represents the DRASTIC rating and weights for each parameter. Each parameter rating is multiplied by the weight to get a value for the parameter (Aller et al., 1987). These values are then summarized to arrive at a pollution index, called DRASTIC index.

The DRASTIC index can be divided into five categories: very low, low, moderate, high and very high. If the site of the study area has a high or very high DRASTIC index value, it means that the area is more vulnerable to contamination and consequently needs to be managed more carefully.

The Rating Number for each factor has been determined as follows:

- Groundwater Depth: The depth to groundwater table in the study area range from $50-300 \mathrm{~m}$ at the wells penetrated the uppermost aquifer (A7/B2).

- Groundwater Recharge: Assuming an effective porosity of 2\%, groundwater recharge would be around 4 $\mathrm{mm} /$ year $(0.4 \mathrm{~cm})$ or $3 \%$ from the total rainfall.

- Topography\%: Generally, the area is rolling to hilly, with some steep wadis and slope more than $18 \%$.

- Hydraulic Conductivity: Due to karst features, joint, sinkholes, caves and solution breccias, A7/B2 aquifer has a wide range of hydraulic conductivity values range from $0.0846 \mathrm{~m} /$ day to $8.64 \mathrm{~m} /$ day.

- Aquifer Media and Vadose Zone Material: The formation (B1) is intercalated between B2 and A7. This formation (B1) composed of alternating marl, marly limestone, chert, and sandstone. A7/B2 formation is an excellent aquifer with permeability varying due to joints, fractures, and karstification of limestone.

Table 1. DRASTIC Rating and Weighting Values for the Hydrogeological Parameter Setting

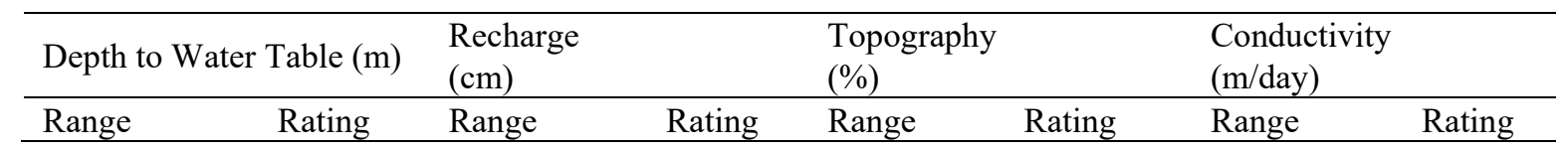




\begin{tabular}{|c|c|c|c|c|c|c|c|}
\hline $0-1.6$ & 10 & $0-5$ & 1 & $0-2$ & 10 & $0.041-4.1$ & 1 \\
\hline $1.6-4.6$ & 9 & $5-10.2$ & 3 & $2-6$ & 9 & $4.1-12.3$ & 2 \\
\hline $4.6-9.1$ & 7 & $10.2-17.8$ & 6 & $6-12$ & 5 & $12.3-28.7$ & 4 \\
\hline $9.1-15.2$ & 5 & $17.8-25.4$ & 8 & $12-18$ & 3 & $28.7-41$ & 6 \\
\hline $15.2-22.9$ & 3 & $>25.4$ & 9 & $>18$ & 1 & $41-82$ & 8 \\
\hline $22.9-30.5$ & 2 & & & & & $>82$ & 10 \\
\hline$>30.5$ & 1 & & & & & & \\
\hline Pollution V & t 5 & \multicolumn{2}{|c|}{ Pollution Weight 4} & Pollutic & eight 3 & \multicolumn{2}{|c|}{ Pollution Weight 2} \\
\hline \multicolumn{4}{|c|}{ Aquifer Media } & \multicolumn{4}{|c|}{ Vadose Zone Material } \\
\hline \multirow{2}{*}{\multicolumn{3}{|c|}{ Massive Shale }} & \multicolumn{3}{|l|}{ Rating } & & Rating \\
\hline & & & & \multicolumn{3}{|c|}{ Confining Layer } & 1 \\
\hline \multicolumn{3}{|c|}{ Metamorphic / Igneous } & & \multicolumn{3}{|c|}{ Silt / clay } & 3 \\
\hline \multicolumn{3}{|c|}{ Weather Metamorphic Igneous } & & \multicolumn{3}{|l|}{ Shale } & 3 \\
\hline \multicolumn{3}{|c|}{ Glacial Till } & & \multicolumn{3}{|c|}{ Limestone } & 3 \\
\hline \multicolumn{3}{|c|}{ Bedded Sandstone, Limestone } & & Sandst & & & 6 \\
\hline \multicolumn{3}{|c|}{ Massive Sandstone } & & \multicolumn{3}{|c|}{ Bedded Limestone, Sandstone } & 6 \\
\hline \multicolumn{3}{|c|}{ Massive Limestone } & & \multicolumn{3}{|c|}{$\begin{array}{l}\text { Sand and Gravel With Signification } \\
\text { Silt }\end{array}$} & 6 \\
\hline \multicolumn{3}{|c|}{ Sand and Gravel } & & \multicolumn{3}{|c|}{ Sand and Gravel } & 8 \\
\hline \multicolumn{3}{|l|}{ Basalt } & & \multicolumn{3}{|l|}{ Basalt } & 9 \\
\hline \multicolumn{3}{|c|}{ Karst Limestone } & $\mathbf{0}$ & \multicolumn{3}{|c|}{ Karsts Limestone } & 10 \\
\hline \multicolumn{4}{|c|}{ Pollution Weight 3} & \multicolumn{3}{|c|}{ Pollution Weight 3} & \\
\hline \multicolumn{4}{|l|}{ Soil Media } & \multicolumn{4}{|l|}{ Rating } \\
\hline \multicolumn{4}{|l|}{ Gravel } & \multicolumn{4}{|l|}{10} \\
\hline Sand & & & & 9 & & & \\
\hline Peat & & & & 8 & & & \\
\hline Shrinking & & & & 7 & & & \\
\hline Sandy Loa & & & & 6 & & & \\
\hline Loam & & & & 5 & & & \\
\hline Silty Loam & & & & 4 & & & \\
\hline Clay Loam & & & & 3 & & & \\
\hline Pollution V & it 5 & & & & & & \\
\hline
\end{tabular}

Note. Bold values represent the study area.

The DRASTIC Index value for the study area is calculated as presented in Table 2.

Table 2. DRASTIC Index Calculation

\begin{tabular}{lllll}
\hline DRASTIC Factor & Range & Rating & Weight & Result \\
\hline Depth to W.T. $(\mathrm{m})$ & $>30.5$ & 1 & 5 & 5 \\
Recharge $(\mathrm{cm})$ & $0-5(\mathbf{0 . 6} \mathbf{~ c m})$ & 1 & 4 & 4 \\
Topographic/Slope (\%) & $>18$ & 1 & 3 & 3 \\
Conductivity (m/day) & $4.1-12.3 \mathbf{( 0 . 0 8 4 6 - 8 . 6 4 )}$ & 2 & 2 & 4 \\
Aquifer Media & Karst Limestone & 10 & 3 & 30 \\
Vadose Zone Media & Bedded Sandstone, limestone & 6 & 3 & 18 \\
Soil Media & Sand & 9 & 5 & 45 \\
DRASTIC Index & & & & $\mathbf{1 0 9}$ \\
\hline
\end{tabular}


The DRASTIC Index values range from small value to about 65 while the maximum value may exceed 200, which means great potential to pollute the groundwater. The classes of DRASTIC vulnerability index are (Aller et al., 1987):

\begin{tabular}{ll}
\hline Very Low & $65-96$ \\
Low & $96-127$ \\
Moderate & $127-158$ \\
High & $158-189$ \\
Very High & $189-223$ \\
\hline
\end{tabular}

At the study area, the measured DRASTIC Index value was 109 which can be considered as a low vulnerability value. This result means that in the unlikely event that wastewater is discharged from the DWWTS facility to the surrounding environment there is no risk on the groundwater resources and aquifer systems in the area.

\section{Conclusions}

Dana Biosphere Reserve is the largest nature reserve covering all four different bio-geographical zones in Jordan. Springs and groundwater are major sources for drinking water and irrigation activities in Dana's rural communities and visitors' accommodations. No adequate wastewater treatment plant serves these rural communities or the visitors' accommodations within the study area, and unexpected wastewater leakages can have potential groundwater pollution.

DWWTS are environmentally sound and sustainable technology can be used for rural communities such the ones found in the study area. Besides, promoting public health and reducing environmental pollution, wastewater management is most beneficial where it supports groundwater protection. Therefore, priority shall be given to locations where decentralized wastewater management reinforces the remediation of groundwater pollution from wastewater or the prevention of groundwater risks correlated to wastewater.

Groundwater contamination risk is the critical point when implementing wastewater treatment systems including DWWTS. DRASTIC Model was applied to assess the groundwater contamination vulnerability in the study area. The measured DRASTIC index value of 109 indicates that the potential for polluting groundwater in the area is of low vulnerability. Therefore, this study recommends implementing DWWTS to serve communities in Dana Biosphere Reserve area emphasizing the development of groundwater monitoring program during the operation of the facility.

\section{References}

Al Rawabi Environment \& Energy Consultancies (REEC). (2018). Preliminary Environmental Impact Assessment (PEIA) study for Implementation of Decentralized Wastewater Treatment Infrastructure at Feynan Ecolodge, Dana/Tafila Governorate (submitted to GIZ/ACC project and Jordan Ministry of Environment)

Al-Khashman, O. A., Alnawafleh, H. M., Abu, J. A. M., \& Al-Muhtaseb, A. H. (2017). Monitoring and Assessing of Spring Water Quality in Southwestern Basin of Jordan. Open Journal of Modern Hydrology, 7, 331-349, https://doi.org/10.4236/ojmh.2017.74019

Aller, L., Bennett, T., Lehr, J. H., Petty, R. J., \& Hackett, G. (1987). DRASTIC: A Standardized System for Evaluating Groundwater Pollution Potential Using Hydrogeologic Settings, Environmental Protection Agency NWWA/EPA Series EPA-600/2-87-035, National Water Well Association, Dublin.

Bender, F. (1974), Geology of Jordan, Berlin: Gebrüder Borntraeger, 196pp.

Bussmann, A., Dlubatz, L., Khair, A., Matar, F., Nouns, I., Zimmermann, E., \& Zuchold, M. (2014). Feynan Ecolodge Integrated Potential Water and Wastewater Treatment Solutions - Blind Design, Developed by IWRM Alumni Association.

ECO Consult and ECODIT. (2015). Preliminary Environmental Impact Assessment Dana Village Restoration Project (submitted to RSCN, USAID and Jordan Ministry of Environment).

GIZ/ACC Project. (2016). Decentralized Wastewater Management for Adaption to Climate Change in Jordan, Decentralized Wastewater Management: The Challenge.

Jamaliah, M. M., \& Powell, R. B. (2017). Ecotourism resilience to climate change in Dana Biosphere Reserve, Jordan, Journal of Sustainable Tourism. https://doi.org/10.1080/09669582.2017.1360893

Japan International Cooperation Agency (JICA). (2001). The Study on Water Resources Management in The Hashemite Kingdom of Jordan, Final Report/Supporting Report Part-A "MasterPlan,", Supporting Report 
for "Chapter 2 Water Resources Potential and DevelopmentPlan.n".

Jordan Meteorological Department. (2018).

Jordan Ministry of Water and Irrigation. (2012).

Jordan Ministry of Water and Irrigation (2016). Decentralized Wastewater Management Policy.

Powell, J. H., Abed, A. M., \& Le Nindre, Y. (2014). Cambrian stratigraphy of Jordan, GeoArabia, v. 19, no. 3, p. 81-134. RSCN. $\quad$ Retrieved $19^{\text {th }} \quad$ Jan., $2019, \quad$ from https://www.rscn.org.jo/sites/default/files/publication/DANA-EN.pdf

Sasse, L. (1998). Decentralized Wastewater Treatment in Developing Countries, BORDA

US EPA (Environmental Protection Agency). (1985). DRASTIC: A standard system for evaluating groundwater potential using hydrogeological settings, Ada, Oklahoma WA/EPA Series, 163 pp.

\section{Copyrights}

Copyright for this article is retained by the author(s), with first publication rights granted to the journal.

This is an open-access article distributed under the terms and conditions of the Creative Commons Attribution license (http://creativecommons.org/licenses/by/4.0/). 